\title{
Methanol Oxidation Activity of Pt Oxide Black Treated by Electrochemical Reduction
}

\author{
Masami TAGUCHI $^{a}$, Yasuhiro KAWAHASHI ${ }^{b}$ and Yuuki KOSAKA ${ }^{b}$ \\ ${ }^{a}$ Department of Materials Science and Engineering, \\ Graduate School of Engineering and Resource Science, Akita University, \\ Akita 010-8502, Japan \\ ${ }^{\mathrm{b}}$ Graduate Student, Akita University \\ E-mail :taguchi@ipc.akita-u.ac.jp
}

\begin{abstract}
For the development of a novel anode catalyst for use in a DMFC, Pt oxide blacks were partially reduced by electrochemical treatment, and the electrocatalytic activities of the methanol oxidation were investigated by the rotating disk electrode method. Specific surface area measurement of the active sites by CO stripping voltammetry, analysis of the chemical shift by XPS and determination of the O/Pt atomic ratio by EPMA were also carried out on the reduced Pt oxide blacks. Compared to the Pt oxide black without reduction, the methanol oxidation activity of the partially reduced $\mathrm{Pt}$ oxide black was significantly improved by applying the cathodic charge of $-0.6 \mathrm{C}$ or more. The Pt oxide black reduced by $-1.2 \mathrm{C}$ had particularly good properties, namely, the anode catalyst showed both the highest current density and the minimum activation energy of the methanol oxidation. The methanol oxidation activity of the Pt oxide black, which was effectually enhanced by the electrochemical reduction, exceeded that of the anode catalyst now in use or PtRu black. Furthermore, the XPS and EPMA analyses suggested that the residual oxygen in the partially reduced Pt oxide black played an important role in the methanol oxidation.
\end{abstract}

Key Words : Pt oxide black, DMFC, Anode catalyst, Electrochemical reduction, Methanol oxidation.

\section{Introduction}

The direct methanol fuel cell (DMFC), in which the methanol is directly injected into the anode, is expected to be a promising power supply for potable equipment, since the cell does not need a fuel processor and can be downsized ${ }^{1)}$. However, there are some significant technical problems, i.e., a low power density resulting from the low activity of the catalyst, $\mathrm{CO}$ poison, etc. The CO poison, which is a chemical phenomenon that involves the intermediate of the methanol oxidation or the $\mathrm{CO}$ molecules adsorbed on the catalyst surface thus retarding the subsequent reactions, produces a significant decrease in the DMFC performance. A PtRu black ${ }^{2) 3}$, which has a tolerance to the $\mathrm{CO}$ adsorption, was developed in order to improve the performance of the methanol oxidation and it became the current anode catalyst in recent DMFCs. The role of Ru can be interpreted in that $\mathrm{Ru}$ affects the electronic state of the Pt and weakens the Pt-CO bond, or Ru oxidizes $\mathrm{H}_{2} \mathrm{O}$ to produce the $\mathrm{Ru}-\mathrm{OH}_{\mathrm{ad}}$ and the $\mathrm{Ru}-\mathrm{OH}_{\mathrm{ad}}$ promotes the oxidation of the $\mathrm{CO}_{\mathrm{ad}}{ }^{4-6)}$. Currently, the catalytic activity of the $\mathrm{PtRu}$ black is not yet sufficient for use in the popular DMFCs.

In addition, the author et al. prepared several Pt oxide films with various compositions by reactive sputtering and then scientifically investigated the relationship between the methanol oxidation activity and the $\mathrm{O} / \mathrm{Pt}$ atomic ratio of the $\mathrm{Pt}$ oxide films ${ }^{78)}$. The investigation revealed that the reducing treatment significantly improved the methanol oxidation activity of the Pt oxide film, although the activity of the Pt oxide film was extremely low as it was. The chemical analysis by using XPS and EPMA also suggested that the residual oxygen was strongly related to the high catalytic activity of the partially reduced Pt oxide films. However, if the reduced Pt oxide is used as the practical catalyst of the DMFC, the filmy shape is unfavorable to promote the reaction. In other words, it is very important to change the shape of the catalyst from a film to fine particles with a high specific surface area.

In this study, the Pt oxide black was chosen as the starting material of a novel anode catalyst since it is composed of innumerable fine particles with a high specific surface area, and the effect of the electrochemical reduction on the methanol oxidation activity of the Pt oxide black was investigated. That is to say, the rotating disk electrode with the Pt oxide black catalyst was electrochemically reduced by charging with a cathodic current and the anodic polarization curve was measured in order to evaluate the methanol oxidation activity of the reduced Pt oxide black in a $\left(\mathrm{H}_{2} \mathrm{SO}_{4}+\mathrm{CH}_{3} \mathrm{OH}\right)$ solution. The specific surface area and the chemical shift of the reduced Pt oxide black were also analyzed by $\mathrm{CO}$ stripping voltammetry ${ }^{9)}$ and X-ray photoelectron spectroscopy ${ }^{10) 11)}$, respectively, since the methanol oxidation probably proceeds on the active sites newly produced by the electrochemical reduction. Based on the results obtained in these experiments, the cause of the high methanol oxidation activity in the electrochemically reduced Pt oxide black is discussed. 


\section{Experimental}

\subsection{Preparation of catalyst layer}

A catalyst layer of Pt oxide black for methanol oxidation was prepared on a glassy carbon rod (Tokai Carbon, GC20SS, $5.0 \mathrm{~mm}$ diameter, $10.0 \mathrm{~mm}$ height) as follows. A Pt oxide black (Wako, purity; $95.0 \mathrm{mass} \%$ ) of $20.6 \mathrm{mg}$, a carbon powder (Cabot, Valcan XC-72R) of $10.3 \mathrm{mg}$ and a Nafion ${ }^{\circledR}$ alcoholic solution (Ardrich, purity; 5 mass $\%$ ) of $1000 \mu 1$ were mixed in a glass mortar. By milling and shaking of the mixture by ultrasonics, a homogeneous suspension was obtained. A suspension of $5.0 \mu 1$ was then dropped on the cross section of the glassy carbon rod (area; $19.6 \mathrm{~mm}^{2}$ ) and it was evaporated at $348 \mathrm{~K}$ for $300 \mathrm{~s}$ to make a Pt oxide black catalyst layer. By a similar procedure, a catalyst layer of PtRu black (Pt; 61.0 mass\%, Ru; 31.6 mass\%) was also prepared on a glassy carbon rod for the evaluation test. The PtRu black was supplied by a manufacturer of catalyst materials.

\subsection{Evaluation of methanol oxidation activity of catalyst}

The methanol oxidation activity of the catalyst layer was evaluated by the anodic polarization method using a rotating disk electrode $^{8 / 2)}$. Figure 1 shows the rotating disk electrode with the catalyst layer. The glassy carbon rod with the catalyst layer of Pt oxide black or PtRu black was attached to this electrode, and the electrode was then attached to a rotating electrode system (Hokuto Denko, HR-200) as the working electrode of the anodic polarization. The counter electrode and the reference electrode were a Pt black spiral and an $\mathrm{Ag} / \mathrm{AgCl}$ electrode in $3.30 \mathrm{kmol} \mathrm{m}^{-3}$ $\mathrm{KCl}$, respectively. All the measured potentials were quoted with respect to the normal hydrogen electrode (NHE). The electrolyte was a $\left(0.5 \mathrm{kmol} \mathrm{m}^{-3} \mathrm{H}_{2} \mathrm{SO}_{4}+1.0 \mathrm{kmol} \mathrm{m}^{-3} \mathrm{CH}_{3} \mathrm{OH}\right)$ solution, which had been previously deoxygenated by bubbling with high purity argon. The temperature of the solution was gradually changed from 298 to $313 \mathrm{~K}$, but the rotation rate of the specimen electrode was fixed at $900 \mathrm{rpm}$. The anodic polarization curves in the potential range of 0.67 to $1.32 \mathrm{~V}$ vs. NHE were measured at the sweep rate of $5 \mathrm{mV} \mathrm{s}^{-1}$ using a potentiostat (Hokuto Denko, HZ-5000).

\subsection{Electrochemical reduction of catalyst layer}

The catalyst layer of Pt oxide black was partially reduced by the electrochemical method. The working electrode and the counter electrode were a rotating disk electrode with Pt oxide black and a Pt black spiral, respectively. The cathodic current of $-1.0 \mathrm{~mA}$ was passed to the working electrode for $100 \mathrm{~s}$ in order to reduce the catalyst layer of the Pt oxide black by the electric charge of $-0.1 \mathrm{C}$. The cathodic charge of $-0.1 \mathrm{C}$ was repeated at most 20 times to be $-2.0 \mathrm{C}$. After each electrochemical reduction, the anodic polarization was carried out on the partially reduced $\mathrm{Pt}$ oxide black in order to evaluate the methanol oxidation activity.

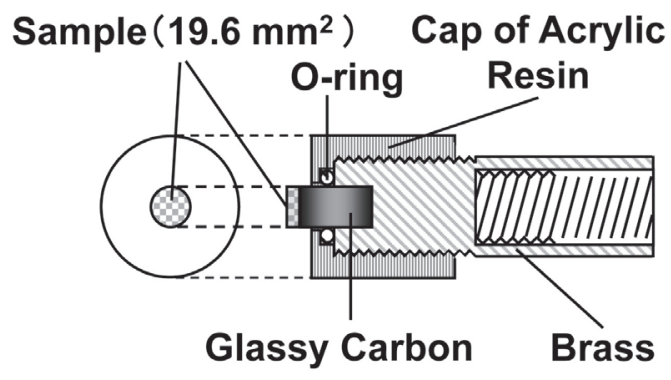

Figure 1 Rotating disk electrode with catalyst layer.
On the other hand, the chemical shift of the Pt oxide black without reduction and those of the reduction products were analyzed by X-ray photoelectron spectroscopy (JEOL, JPS9000SX) with Mg $\mathrm{K} \alpha$ radiation. The accelerating voltage and the emission current of the XPS were $10 \mathrm{kV}$ and $20 \mathrm{~mA}$, respectively. The $\mathrm{O} / \mathrm{Pt}$ atomic ratios of all the catalysts were also analyzed by EPMA (JEOL, JSM-5900LV) using an electron beam of $20 \mathrm{kV}$.

\subsection{CO stripping voltammetry}

The active surface area of the Pt oxide black without reduction and those of the products by electrochemical reduction were estimated by $\mathrm{CO}$ stripping voltammetry ${ }^{4) 9}$. The working electrode was a fixed glassy carbon with a catalyst layer. The counter electrode and the reference electrode were a Pt mesh and an $\mathrm{Ag} /$ $\mathrm{AgCl}$ electrode, respectively. The measurement was carried out in a $0.5 \mathrm{kmol} \mathrm{m}^{-3} \mathrm{H}_{2} \mathrm{SO}_{4}$ solution at $298 \mathrm{~K}$, which was deoxygenated by bubbling of a high purity argon. $\mathrm{CO}$ molecules were first adsorbed on the surface of the working electrode by flowing $\mathrm{Ar}-0.1 \% \mathrm{CO}$ (Taiyou Nissan, CO; 0.101 vol.\%.) at the flow rate of $2.5 \mathrm{ml} \mathrm{s}^{-1}$ through the working electrode compartment. In other words, the working electrode was temporarily removed from the solution and it kept in the $\mathrm{Ar}-0.1 \% \mathrm{CO}$ atmosphere for $1.8 \mathrm{ks}$. After the $\mathrm{CO}$ adsorption on the active surface of the catalyst layer, the working electrode was placed in the solution again and the voltammetry in the potential range from 0.12 to $1.22 \mathrm{~V}$ vs. NHE was repeated twice at the sweep rate of $10 \mathrm{mV} \mathrm{s}^{-1}$. The active surface area of the catalyst layer was estimated by the difference in the oxidation current of the adsorbed $\mathrm{CO}$ between the first voltammogram and the second one.

\section{Results and Discussion}

\subsection{Influence of electrochemical reduction on methanol} oxidation activity of $\mathrm{Pt}$ oxide black

Figure 2 shows the anodic polarization curves of the rotating disk electrodes with the $\mathrm{Pt}$ oxide black as the electrode catalyst in a $\left(0.5 \mathrm{kmol} \mathrm{m}^{-3} \mathrm{H}_{2} \mathrm{SO}_{4}+1.0 \mathrm{kmol} \mathrm{m}^{-3} \mathrm{CH}_{3} \mathrm{OH}\right)$ solution at $298 \mathrm{~K}$. The Pt oxide black was electrochemically reduced by various cathodic charges from 0 to $-2.0 \mathrm{C}$. After the cathodic reduction of $-1.0 \mathrm{~mA}$ for $100 \mathrm{~s}$ intervals, the polarization measurement at the rotation

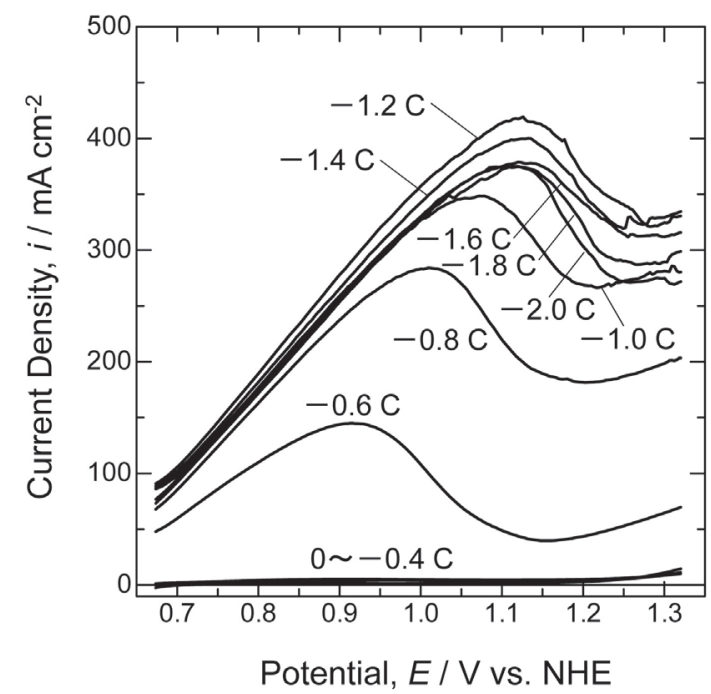

Figure 2 Anodic polarization curves of Pt oxide black electrochemically reduced by various electric charges. The electrolyte solution was $0.5 \mathrm{kmol} \mathrm{m}^{-3} \mathrm{H}_{2} \mathrm{SO}_{4}+1.0 \mathrm{kmol} \mathrm{m}^{-3} \mathrm{CH}_{3} \mathrm{OH}$ at $298 \mathrm{~K}$. 
rate of $900 \mathrm{rpm}$ was repeated in the potential range between 0.675 to $1.325 \mathrm{~V}$ vs. NHE. The anodic current density was only slightly detected for the Pt oxide blacks reduced by the cathodic charge of 0 to $-0.4 \mathrm{C}$. On the other hand, the anodic current was significantly increased by the electrochemical reduction from -0.6 to $-2.0 \mathrm{C}$. Incidentally, these anodic currents were not detected at all in the solution without $\mathrm{CH}_{3} \mathrm{OH}$, namely in a $0.5 \mathrm{kmol} \mathrm{m}{ }^{-3} \mathrm{H}_{2} \mathrm{SO}_{4}$ solution. Therefore, the prerequisite conclusion can be derived from these data that the anodic current peaks in a $\left(0.5 \mathrm{kmol} \mathrm{m}^{-3}\right.$ $\left.\mathrm{H}_{2} \mathrm{SO}_{4}+1.0 \mathrm{kmol} \mathrm{m}^{-3} \mathrm{CH}_{3} \mathrm{OH}\right)$ solution are caused by the oxidation of $\mathrm{CH}_{3} \mathrm{OH}$ on the electrode catalysts. Moreover, the current density of the electrochemically reduced Pt oxide black increased and its potential at the peak current shifted to the more positive direction with the increasing quantity of cathodic current in the range of -0.6 to $-1.2 \mathrm{C}$. That is to say, the peak current density of the Pt oxide black reduced by $-1.2 \mathrm{C}$ amounted to $425 \mathrm{~mA} \mathrm{~cm}^{-2}$ at $1.13 \mathrm{~V}$ vs.

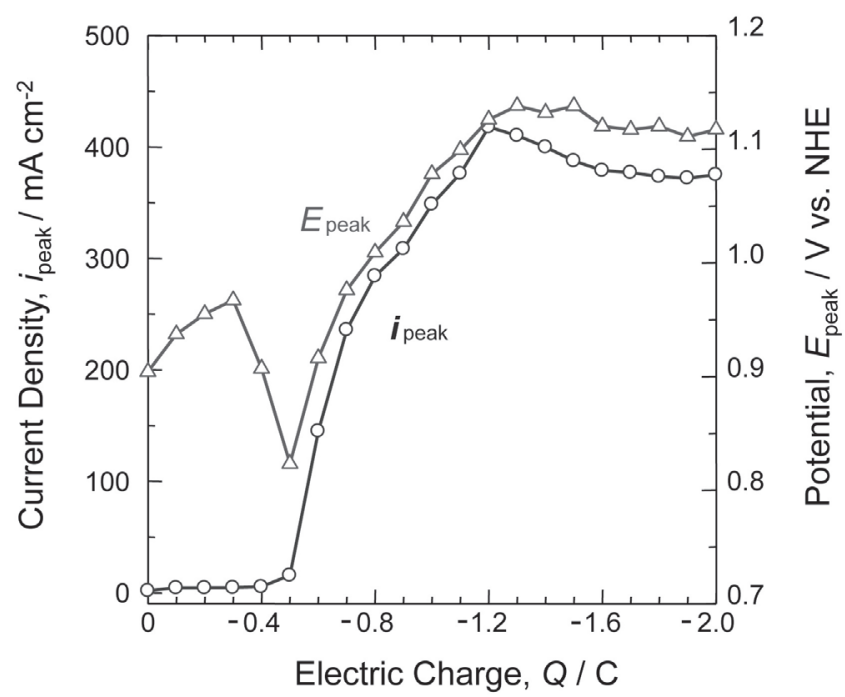

Figure 3 Relationship between electric charge for electrochemical reduction of Pt oxide black, the peak current density, $i_{\text {peak }}$, of methanol oxidation and its electrode potential, $E_{\text {peak }}$, in $0.5 \mathrm{kmol}$ $\mathrm{m}^{-3} \mathrm{H}_{2} \mathrm{SO}_{4}+1.0 \mathrm{kmol} \mathrm{m}^{-3} \mathrm{CH}_{3} \mathrm{OH}$ solution at $298 \mathrm{~K}$.
NHE, which was 2.8 times greater than that of the Pt oxide black reduced by $-0.6 \mathrm{C}, 150 \mathrm{~mA} \mathrm{~cm}^{-2}$ at $0.925 \mathrm{~V}$ vs. NHE. However, the anodic current of the reduced Pt oxide black unexpectedly decreased in the range of -1.6 to $-2.0 \mathrm{C}$.

Figure 3 shows the relationship between the electric charge for the electrochemical reduction and the peak current density, $i_{\text {peak }}$, of the methanol oxidation and the potential at the peak current, $E_{\text {peak }}$, of the reduced Pt oxide black. Compared to the Pt oxide black without reduction, there was no change in the peak current density of the methanol oxidation in the range of 0 to $-0.5 \mathrm{C}$. However, the methanol oxidation activity was significantly improved by passing the cathodic current over $-0.6 \mathrm{C}$ and reached the maximum value of $425 \mathrm{~mA} \mathrm{~cm}^{-2}$ at $-1.2 \mathrm{C}$. On the other hand, the potential of the peak current initially declined almost immediately before the methanol oxidation activity significantly changed. Specifically, the potential of the peak current declined to $0.83 \mathrm{~V}$ vs. NHE in the range of the cathodic charge between -0.4 to $-0.5 \mathrm{C}$. This phenomenon may suggest that the chemical state of the Pt oxide black started changing prior to the improvement of the methanol oxidation activity. The potential of the peak current then changed from 0.92 to $1.12 \mathrm{~V}$ vs. NHE in the range of the cathodic charge between -0.6 to $-1.2 \mathrm{C}$, which correlated to the significant increase in the current density. However, both the anodic current and the potential of the peak current gradually declined over the cathodic charge of $-1.2 \mathrm{C}$.

\subsection{Influence of temperature on methanol oxidation activity of $\mathrm{Pt}$ oxide black reduced by $-1.2 \mathrm{C}$}

Figure 4 shows the anodic polarization curves of (a) Pt oxide black reduced by electric charge of $-1.2 \mathrm{C}$ and (b) PtRu black in a $\left(0.5 \mathrm{kmol} \mathrm{m}^{-3} \mathrm{H}_{2} \mathrm{SO}_{4}+1.0 \mathrm{kmol} \mathrm{m}^{-3} \mathrm{CH}_{3} \mathrm{OH}\right)$ solution at $298-313 \mathrm{~K}$. For (a), the Pt oxide black electrochemically reduced by $-1.2 \mathrm{C}$, the anodic current related to the methanol oxidation appeared from about $0.7 \mathrm{~V}$ vs. NHE and achieved a peak near $0.85 \mathrm{~V}$ vs. NHE. The anodic current increased but the potential of the peak current did not significantly shift with the increasing temperature. On the other hand, it was confirmed for (b), the PtRu black, that the potential of the peak current gradually shifted to the positive direction with the increase in the anodic current. The shift in the

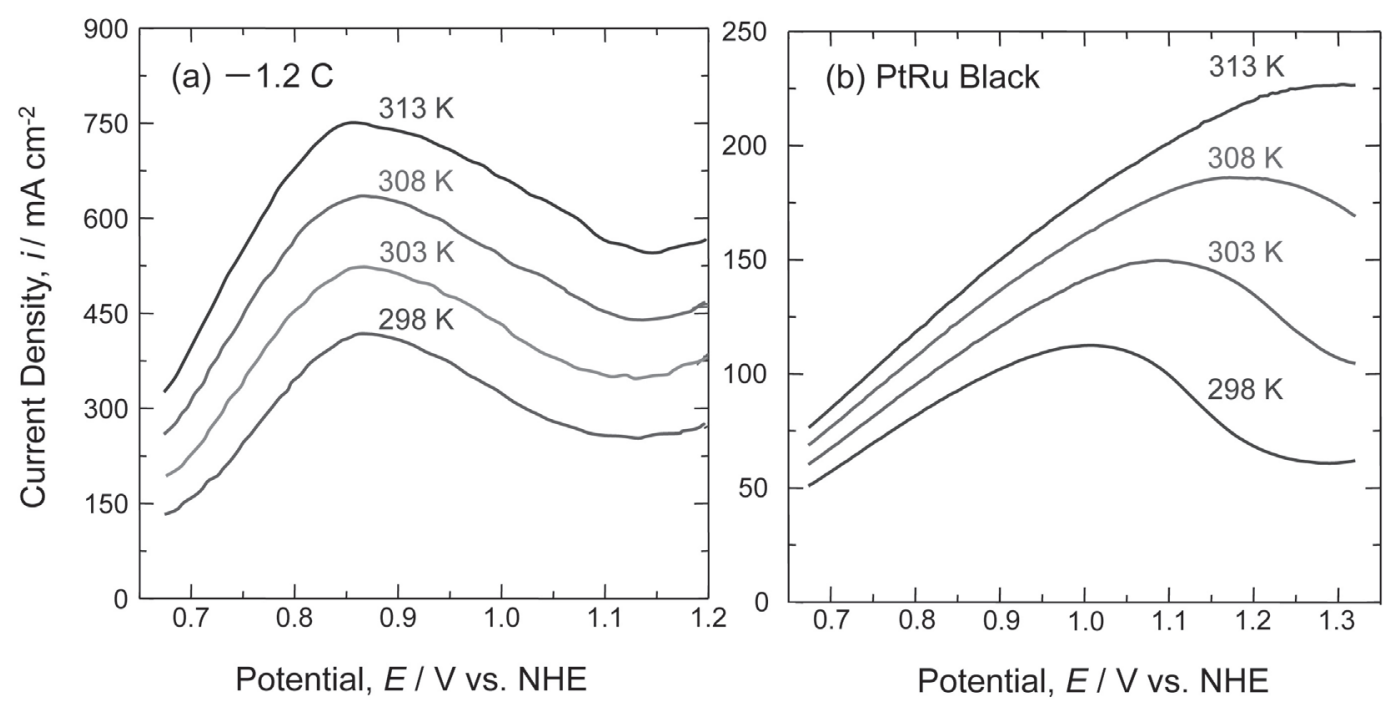

Figure 4 Anodic polarization curves of (a) Pt oxide black reduced by electric charge of $-1.2 \mathrm{C}$ and (b) PtRu Black in $0.5 \mathrm{kmol} \mathrm{m}^{-3} \mathrm{H}_{2} \mathrm{SO}_{4}+1.0 \mathrm{kmol} \mathrm{m}^{-3} \mathrm{CH}_{3} \mathrm{OH}$ at $298-313 \mathrm{~K}$. 
potential suggests that the anodic overvoltage increased with the increasing methanol oxidation current in the case of (b), PtRu black using as a catalyst. Moreover, it is noteworthy that the peak current densities of (a), the Pt oxide black reduced by $-1.2 \mathrm{C}$, are 3.3 3.7 times greater than those of (b), the PtRu black, at the same temperature.

Figure 5 shows an Arrhenius plot of the peak current density, $i_{\text {peak }}$, of the methanol oxidation for the Pt oxide black reduced by the electric charge of $-1.2 \mathrm{C}$ and the PtRu black. A plot of the logarithmic values at the peak current density of the methanol oxidation, $\log i_{\text {peak }}$, vs. the reciprocal of the temperature, $1 / T$, reveals a linear relationship for both anode catalysts. The activation energies for the Pt oxide black reduced by $-1.2 \mathrm{C}$ and the PtRu black, which can be calculated from the slope of the straight line, are equal to 30.5 and $35.9 \mathrm{~kJ} \mathrm{~mol}^{-1}$, respectively. In other words, the electrochemically reduced Pt oxide black was able to promote the methanol oxidation through the pass way with much

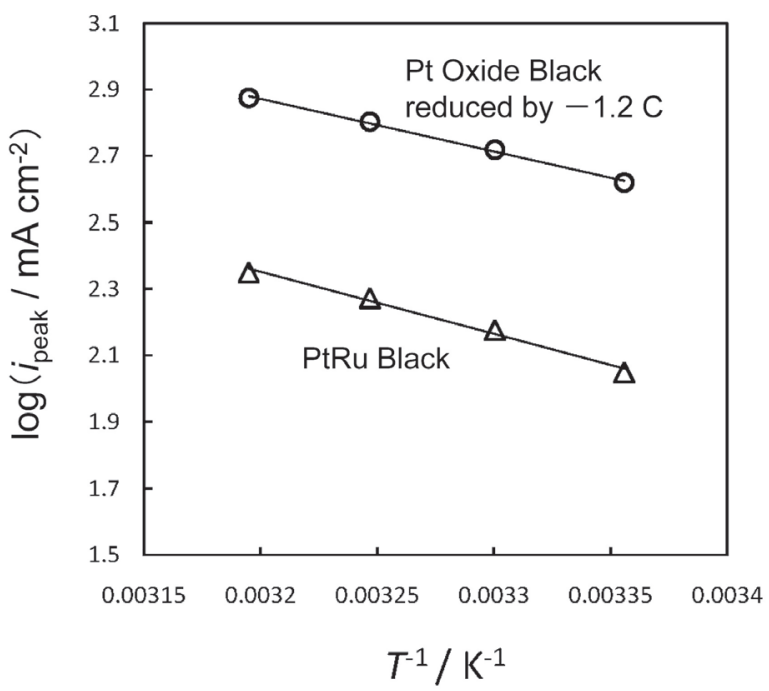

Figure 5 Arrhenius plot of the peak current density, $i_{\text {peak }}$, of methanol oxidation for Pt oxide black reduced by electric charge of $-1.2 \mathrm{C}$ and PtRu Black in $0.5 \mathrm{kmol} \mathrm{m}^{-3} \mathrm{H}_{2} \mathrm{SO}_{4}+1.0 \mathrm{kmol} \mathrm{m}^{-3} \mathrm{CH}_{3} \mathrm{OH}$. lower activation energy than that of the PtRu black. Therefore, it is reasonable to expect that the Pt oxide black electrochemically reduced will be able to replace the catalyst now in use, the PtRu black, as a novel catalyst for the anode reaction in a DMFC.

\subsection{Active surface area of $\mathrm{Pt}$ oxide black reduced electrochemically}

Figure 6 shows the CO stripping voltammograms of (a), the Pt oxide black without reduction, and (b), the Pt oxide black reduced by electric charge of $-0.8 \mathrm{C}$ in a $0.5 \mathrm{kmol} \mathrm{m}^{-3} \mathrm{H}_{2} \mathrm{SO}_{4}$ at $298 \mathrm{~K}$. Each of the stripping voltammograms was measured twice in the potential range from 0.12 to $1.20 \mathrm{~V}$ vs. NHE. When there are adsorbed $\mathrm{CO}$ molecules on the surface of the Pt oxide black, an anodic current peak is always detected around $0.7 \sim 0.8 \mathrm{~V}$ vs. NHE in the first voltammogram related to the oxidation of the adsorbed $\mathrm{CO}$ as follows ${ }^{4) 13(14)}$ :

$$
\mathrm{Pt}-\mathrm{CO}_{\mathrm{ad}}+\mathrm{Pt}-\mathrm{OH}_{\mathrm{ad}} \rightarrow 2 \mathrm{Pt}+\mathrm{CO}_{2}+\mathrm{H}^{+}+\mathrm{e}^{-}
$$

where $\mathrm{Pt}-\mathrm{CO}_{\text {ad }}$ and $\mathrm{Pt}-\mathrm{OH}_{\text {ad }}$ are the adsorbed $\mathrm{CO}$ and $\mathrm{OH}$ on the active site of the Pt oxide black, respectively. An anodic current near $0.2 \sim 0.4 \mathrm{~V}$ vs. NHE is also well-known to be due to the desorption of the adsorbed hydrogen molecules during the CO stripping voltammetry. However, there was no anodic current peak for not only the adsorbed $\mathrm{CO}$, but also the adsorbed hydrogen in the voltammograms of (a), the Pt oxide black without reduction. Therefore, it can be estimated that there was no active site related to the $\mathrm{CO}$ adsorption or hydrogen one on the surface of the Pt oxide black without reduction. For (b), the Pt oxide black electrochemically reduced by the electric charge of $-0.8 \mathrm{C}$, a distinct anodic current peak related to the oxidation of the adsorbed $\mathrm{CO}$ was observed near $0.7 \mathrm{~V}$ vs. NHE in the first stripping voltammogram and it completely disappeared in the second one. Moreover, the anodic current was not detected in the potential range of $0.2 \sim 0.4 \mathrm{~V}$ vs. NHE, which is related to the desorption of the adsorbed hydrogen, in the first stripping voltammogram. However, a low anodic current peak was detected near $0.25 \mathrm{~V}$ vs. NHE in the second stripping voltammogram. The results obtained for (b), the Pt oxide black reduced by $-0.8 \mathrm{C}$, can be interpreted as follows: Some active sites were produced on the
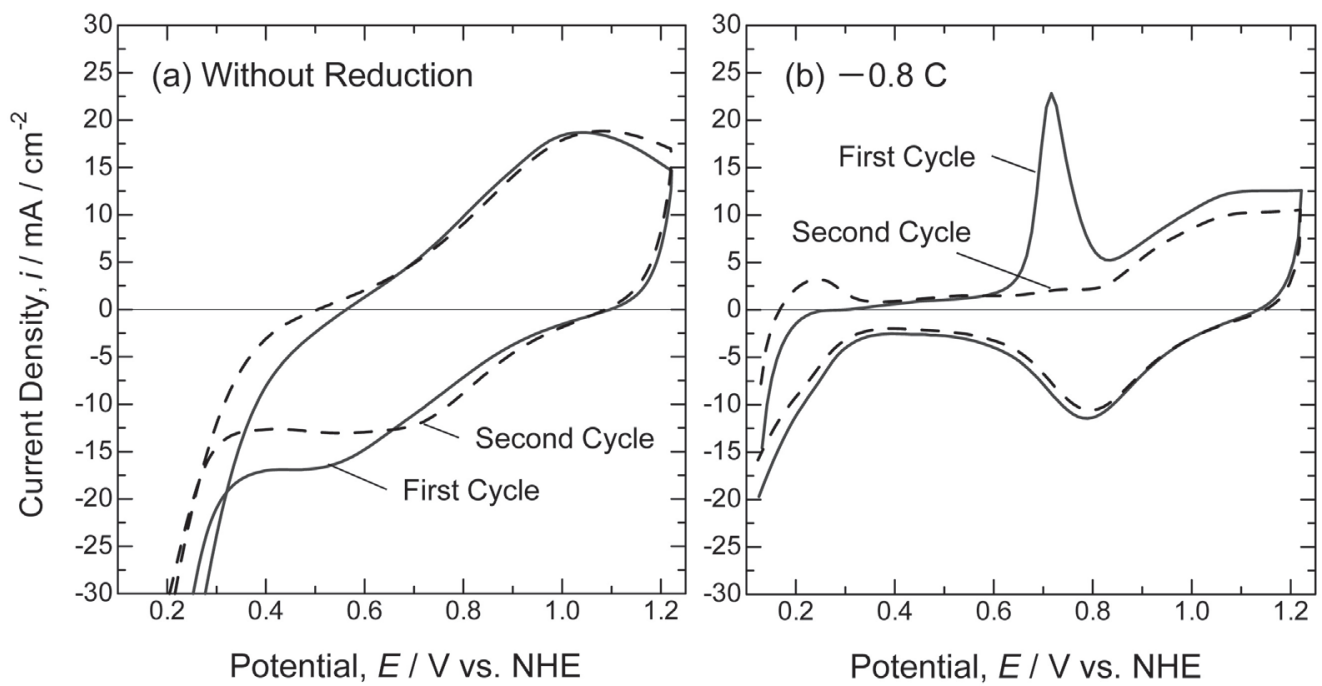

Figure 6 CO stripping voltammograms of (a) Pt oxide black without reduction and (b) Pt oxide black reduced by electric charge of $-0.8 \mathrm{C}$ in $0.5 \mathrm{kmol} \mathrm{m}^{-3} \mathrm{H}_{2} \mathrm{SO}_{4}$ at $298 \mathrm{~K}$. 
surface of the Pt oxide black by the electrochemical reduction and those sites sufficiently adsorbed the $\mathrm{CO}$ molecules. The adsorbed $\mathrm{CO}$ was oxidized to be desorbed from the active sites during the potential sweep of the first voltammogram in the positive direction and then the hydrogen molecules were adsorbed on the active site in exchange of the $\mathrm{CO}$ during the potential sweep in the negative direction. An anodic current for the desorption of the hydrogen molecules was newly observed during the potential sweep in the positive direction of the second stripping voltammogram. Therefore, the amount of the active sites on the surface of the Pt oxide black, $s\left(\mathrm{~cm}^{2}\right)$, which was produced by the electrochemical reduction, can be calculated from the electric charge related to the desorption of the adsorbed $\mathrm{CO}$ near $0.7 \mathrm{~V}$ vs. NHE, $Q(\mathrm{mC})$, as follows $^{944)}$ :

$$
s=Q /\left(\theta \times 0.420 \mathrm{mC} \mathrm{cm}^{-2}\right)
$$

where $\theta$ is the $\mathrm{CO}$ monolayer coverage under saturation, and $0.420 \mathrm{mC} \mathrm{cm}^{-2}$ corresponds to an electric charge for the 2-electron oxidation of the $\mathrm{CO}$ monolayer. Since the electric charge for the oxidation of the adsorbed $\mathrm{CO}, Q$, is equivalent to the difference between the charge of the anodic current of the first voltammogram and that of the second one in the potential range of the $\mathrm{CO}$ oxidation (See Figure 6), the value was calculated to be $38.6 \mathrm{mC}$. The Pt oxide black of $0.412 \mathrm{mg}$ was also loaded on the working electrode as the catalyst. Based on the assumption that the $\mathrm{CO}$ monolayer coverage under saturation, $\theta$, is equal to 1 , the specific active surface area, $S$, was calculated to be $22.3 \mathrm{~m}^{3} \mathrm{~g}^{-1}$ for (b), the Pt oxide black electrochemically reduced by $-0.8 \mathrm{C}$.

Figure 7 shows the relationship between the electric charge for the electrochemical reduction of the Pt oxide black, the peak current density, $i_{\text {peak }}$, of the methanol oxidation and the specific active surface area, $S$, of the reduced Pt oxide black obtained by $\mathrm{CO}$ stripping voltammetry. Measurements of the active surface area were made on the Pt oxide black without reduction and the reduced Pt oxide blacks by the electric charges of $-0.2,-0.4,-0.8,-1.2$, -1.6 and $-2.0 \mathrm{C}$. For the Pt oxide black without reduction, the active surface area was judged to be zero since the anodic current

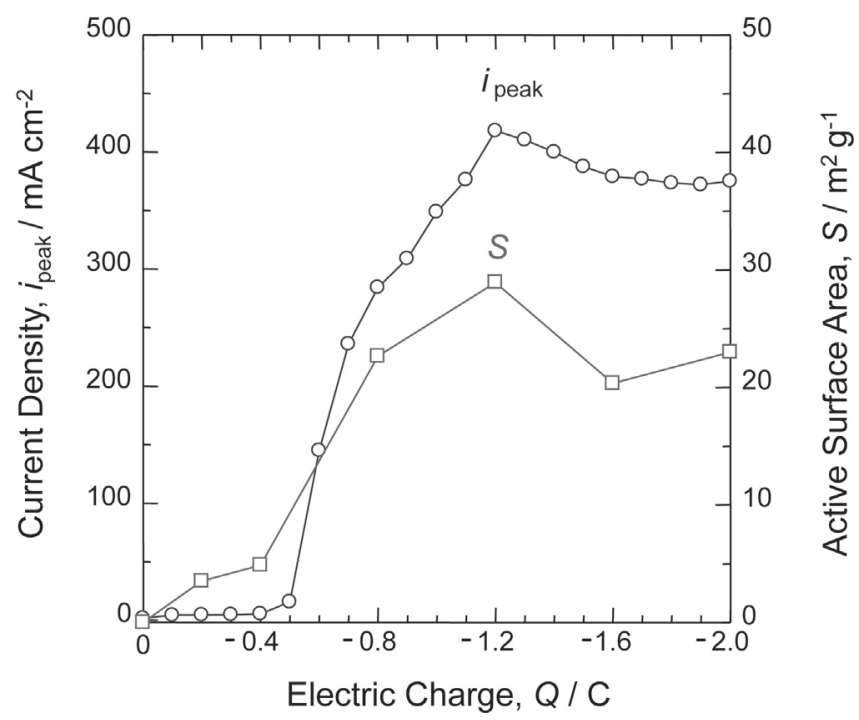

Figure 7 Relationship between electric charge for electrochemical reduction of Pt oxide black, the peak current density, $i_{\text {peak }}$, of methanol oxidation and the specific active surface area, $S$, of the reduced $\mathrm{Pt}$ oxide black. peak for the oxidation of the adsorbed $\mathrm{CO}$ could not be detected at all. The active surface areas of the Pt oxide blacks reduced by -0.2 and $-0.4 \mathrm{C}$ were low, $4 \sim 5 \mathrm{~m}^{2} \mathrm{~g}^{-1}$, whereas the areas significantly increased more than the electric charge of $-0.4 \mathrm{C}$ to be 22.3 and $28.9 \mathrm{~m}^{2} \mathrm{~g}^{-1}$ at -0.8 and $-1.2 \mathrm{C}$, respectively. However, the active surface areas trended downward more than $-1.6 \mathrm{C}$ and the surface area of the Pt oxide black reduced by $-2.0 \mathrm{C}$ was only $23.0 \mathrm{~m}^{2} \mathrm{~g}^{-1}$. The SEM analysis also revealed that there were many cracks in the catalyst layers of the working electrodes electrochemically reduced by -1.6 and $-2.0 \mathrm{C}$ compared to the other electrodes. Therefore, the cause of the unexpected decrease in the specific active surface areas at -1.6 and $-2.0 \mathrm{C}$ can be explained by the fact that a portion of the catalyst layer dissolved or peeled off. In addition, it should be noted that the methanol oxidation activity of the reduced Pt oxide black has a close correlation to its active surface area obtained by the $\mathrm{CO}$ stripping voltammetry. The active surface areas of the reduced Pt oxide black by $-0.2 \mathrm{C}$ or $-0.4 \mathrm{C}$ were small and their methanol oxidation currents were very low, i.e., $5 \mathrm{~mA}$ $\mathrm{cm}^{-2}$ or less, whereas not only the active surface area, but also the methanol oxidation current significantly increased for the $\mathrm{Pt}$ oxide black reduced at $-0.8 \mathrm{C}$ or $-1.2 \mathrm{C}$. Moreover, the methanol oxidation current somewhat decreased and the active surface area equally decreased for the electrochemical reduction of $-1.6 \mathrm{C}$ or $-2.0 \mathrm{C}$. Therefore, we can provide one possible conclusion that the active surface area produced by the electrochemical reduction is directly linked to the methanol oxidation activity of the reduced $\mathrm{Pt}$ oxide black.

3.4 Chemical shift of electrochemically reduced $\mathrm{Pt}$ oxide black

Figure 8 shows the $\mathrm{x}$-ray photoelectron spectra of the $\mathrm{Pt}$ oxide blacks reduced by electric charges of (a) $-0.4 \mathrm{C}$ and (b) $-1.2 \mathrm{C}$. The binding energies of 70.9, 72.4 and $75.6 \mathrm{eV}$, which are represented by the dashed lines in the figure, correspond to the metallic $\mathrm{Pt}, \mathrm{PtO}$ and $\mathrm{PtO}_{2}$ at the $\mathrm{Pt}_{4} \mathrm{f}_{7 / 2}$ energy level, respectively ${ }^{8) 15(16)}$. There are two strong peaks of 73.0 and $76.0 \mathrm{eV}$ in the spectrum of (a), the Pt oxide black reduced by $-0.4 \mathrm{C}$, which had little or no activity on the methanol oxidation (See Figure 4). These peaks correspond to the binding energies of the $\mathrm{Pt}_{4 \mathrm{f}}$ and $\mathrm{Pt}_{45 / 2}$ levels, respectively. The former binding energy of $73.0 \mathrm{eV}$ is close to the binding energy of $\mathrm{PtO}$, i.e., $72.4 \mathrm{eV}$. The quantitative analysis using EPMA revealed that the average of $\mathrm{O} / \mathrm{Pt}$ atomic ratio was 1.93 for the Pt oxide black without reduction. In addition, the XPS analysis confirmed that the original Pt oxide black corresponded to $\mathrm{PtO}_{2}$ as the chemical compound. Therefore, it can be interpreted that the electric charge of $-0.4 \mathrm{C}$ reduced the $\mathrm{PtO}_{2}$ to $\mathrm{PtO}$, but did not lead to the production of the metallic Pt. For (b), the Pt oxide black electrochemically reduced by $-1.2 \mathrm{C}$, the binding energies of the spectra corresponding to $\mathrm{Pt}_{4} \mathrm{f}_{7 / 2}$ and $\mathrm{Pt}_{4} \mathrm{f}_{5 / 2}$ were approximately 71.2 and $74.6 \mathrm{eV}$, respectively. Sathe et al. ${ }^{10)}$ had prepared Pt nanoparticles by a specific method and reported that the binding energies of $\mathrm{Pt}_{4} \mathrm{f}_{7 / 2}$ and $\mathrm{Pt} 4 \mathrm{f}_{5 / 2}$ in the spectra of the particles after the electrochemical measurement were shifted to 71.0 and $74.3 \mathrm{eV}$, respectively. They also found that there was a broad peak of about $76.7 \mathrm{eV}$ in the shoulder of the $\mathrm{Pt}_{4 \mathrm{f}_{5 / 2}}$ level and explained that the broad peak corresponded to a Pt oxide, $(\mathrm{PtO})_{\mathrm{x}}$, in addition to the result of the analysis of the O1s spectrum ${ }^{17) 18)}$. The binding energy of the shoulder in the spectrum of (b), the Pt oxide black reduced by $-1.2 \mathrm{C}$, is consistent with the binding energy of the $(\mathrm{PtO})_{\mathrm{x}}$ reported by Sathe et al. The result of the quantitative analysis by EPMA also supported the fact that there was a little 
residual oxygen in the electrochemically reduced Pt oxide black used in this study. Therefore, it can be estimated that the original $\mathrm{Pt}$ oxide black, $\mathrm{PtO}_{2}$, was not completely reduced to the metallic $\mathrm{Pt}$, but $\mathrm{Pt}$ oxide, $(\mathrm{PtO})_{\mathrm{x}}$, partially remained in the product after the electrochemical reduction.

\subsection{Influence of residual oxygen on methanol oxidation activity of electrochemically reduced $\mathrm{Pt}$ oxide black}

The data in Figures 2 and 3 demonstrated that the electrochemical reduction significantly enhanced the methanol oxidation activity of the Pt oxide black as a catalyst. In other words, the Pt oxide black without electrochemical reduction had little or no anodic current of the methanol oxidation. However, the anodic current increased by the cathodic charge of $-0.6 \mathrm{C}$ or more and it attained the maximum value of $425 \mathrm{~mA} \mathrm{~cm}^{-2}$ at $-1.2 \mathrm{C}$. The maximum value was $3.3 \sim 3.7$ times higher than the anodic current of the methanol oxidation of the PtRu blacks, which are the anode catalyst for the current DMFC. On the other hand, the Pt oxide black reduced by $-1.2 \mathrm{C}$ showed the highest value of $28.9 \mathrm{~m}^{2} \mathrm{~g}^{-1}$ for the specific active surface area measured by CO stripping voltammetry, while the area of the Pt oxide black without electrochemical reduction was almost zero. When the electric charge exceeded $-1.2 \mathrm{C}$, the active surface area related to the $\mathrm{CO}$ adsorption tended to decrease as well as the methanol oxidation activity of the reduced Pt oxide black. Based on these results, we can realize the conclusion that the increase in the active surface area caused by the electrochemical reduction was directly related to the high activity of the methanol oxidation of the reduced Pt oxide black.

Moreover, the XPS analysis and EPMA data demonstrated that a $\mathrm{Pt}$ oxide of $(\mathrm{PtO})_{\mathrm{x}}$ remained in the Pt oxide black reduced by $-1.2 \mathrm{C}$ although the chemical composition was approaching that of the metallic Pt and there was a distinct XPS peak of Pt. After the electric charge of $-0.4 \mathrm{C}$, the Pt oxide black was not significantly reduced and had the composition near PtO, and there was no XPS peaks related to the metallic Pt. Therefore, the maximum value of the active surface area at $-1.2 \mathrm{C}$ in the reduced Pt oxide blacks was probably caused by a significant increase in the active sites with the chemical composition of almost metallic Pt during the electrochemical reduction. However, the previous investigations of the metallic Pt and the Pt oxide black films produced by reactive sputtering have already revealed that the origin of the high activity of the methanol oxidation by the electrochemical reduction is an effect specific only to the Pt oxide black. In other words, the electrochemical reduction produced a significant increase in the methanol oxidation activity of only the Pt oxide films produced in the oxygen plasma, whereas it did not affect the metallic Pt film at all in the argon plasma. This fact suggested that the residual oxygen plays a very important role in the origin of the high methanol oxidation activity in the electrochemically reduced $\mathrm{Pt}$ oxide blacks. Therefore, it can be interpreted that the residual oxygen is essential for the high activity of the methanol oxidation of a novel catalyst, which was prepared by the electrochemical reduction of the Pt oxide black as the starting material, as well as increasing the active surface area with the chemical composition near the metallic Pt. Hereafter, the role of the residual oxygen on the prime reactions should be integrated into the activity of the methanol oxidation.

\section{Conclusions}

The Pt oxide black was electrochemically reduced and the relationship between the electric charge for reduction and the methanol oxidation activity of the reduction product was investigated in order to produce a novel metal oxide as the anode catalyst of a DMFC. The measurement of the active surface area by CO stripping voltammetry and the XPS analysis of the chemical shift were also carried out for the reduced Pt oxide blacks. Based on the results and obtained observations, the following conclusions were suggested:

(1) The methanol oxidation activity of the electrochemically reduced Pt oxide black significantly increased by cathodic current charging of more than $-0.6 \mathrm{C}$ for a maximum of $425 \mathrm{~mA} \mathrm{~cm}^{-2}$ at $-1.2 \mathrm{C}$, whereas there was little or no anodic current of the methanol oxidation for the Pt oxide black without reduction. The apparent activation energy of the former for the methanol oxidation was $28.9 \mathrm{~kJ} \mathrm{~mol}^{-1}$, which was $5.4 \mathrm{~kJ} \mathrm{~mol}^{-1}$ lower than that of the latter.

(2) The active surface area of the $\mathrm{CO}$ adsorption was negligibly low for the Pt oxide black without reduction. The active surface
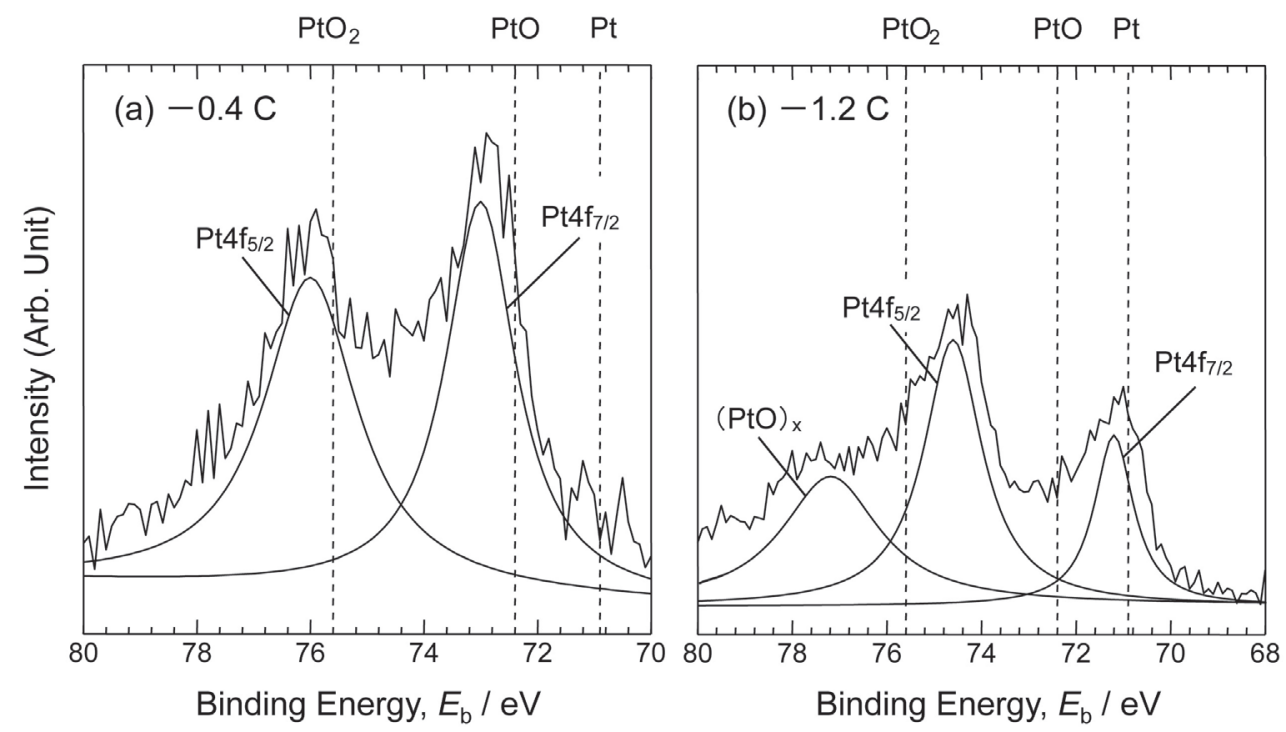

Figure 8 X-ray photoelectron spectra of Pt oxide blacks reduced by electric charge of (a) $-0.4 \mathrm{C}$ or (b) $-1.2 \mathrm{C}$. 
area of the Pt oxide black also increased with the increasing electric charge for the electrochemical reduction to obtain a maximum value of $28.9 \mathrm{~m}^{2} \mathrm{~g}^{-1}$ at $-1.2 \mathrm{C}$. It was determined that the increasing active surface area directly corresponded to a significant improvement in the methanol oxidation activity of the electrochemically reduced Pt oxide black, because the change in the active surface area vs. the electric charge for the electrochemical reduction was consistent with that of the methanol oxidation activity.

(3) The Pt oxide black without reduction was judged to be $\mathrm{PtO}_{2}$, because the $\mathrm{O} / \mathrm{Pt}$ atomic ratio was near 2, in addition to the results of the XPS analysis. For the Pt oxide black electrochemically reduced by $-1.2 \mathrm{C}$, the XPS peak corresponding to the metallic $\mathrm{Pt}$ appeared and the active sites with the chemical composition close to that of the metallic Pt significantly increased. However, there was a little residual oxygen in the reduction product, which can be presumed to have an important role in promoting the methanol oxidation.

\section{Referrences}

1) T. Honma et al.; Hydrogen/Fuel Cell Handbook, p.329 (Ohmsha, 2006).

2) J. L. Gómez de la Fuente, F. J. Pérez-Alonso, M. V. MartinezHuerta, M. A. Peña, J. L. G. Fierro, S. Rojas; Catalysis Today, 143, 69 (2009).

3) F. Peng, C. Zhou, H. Wang, H. Yu, J. Liang, J. Yang; Catalysis Communications, 10, 533 (2009) .

4) Y. Takasu et al.; Fuel Cell Characterization Methods, p.119
(Kagakudojin, 2005).

5) M. Watanabe, S. Motoo; J. Electroanal. Chem., 60, 267 (1975).

6) T. Yajima, H. Uchida, M. Watanabe; J. Phys. Chem. B, 108, 2654 (2004).

7) M. Taguchi, J. Nakayama: Proc. 6th Int. Conf. Mater. Eng. Resour., p.386 (J. Soc. Mater. Eng. Resour., Jpn, 2009).

8) M. Taguchi, J. Nakayama, K. Itou, N. Nagai; Int. J. Soc. Mater. Eng. Resour., 17, 15 (2009).

9) T. Vidaković, M. Christov, K. Sundmacher; Electrochimica Acta, 52, 5606 (2007)

10) B. R.Sathe, M. S.Risbud, S. Patil, K.S.Ajayakumar, R. C. Naik, I. S.Mulla, V. K.Pillai:Sensors and Actuators A, 138, 376 (2007) .

11) C. Chen, G. Levitin, D. W. Hess, T. F. Fuller: J. Power Sources, 169, 288 (2007).

12) M. Taguchi, H. Tamori, W. H. Smyrl; Int. J. Soc. Mater. Eng. Resour., 13, 141 (2006) .

13) T. Kawaguchi, W. Sugimoto,Y. Murakami, Y. Takasu; Electrochem. Commun., 6, 480 (2004).

14) Y. Takasu, T. Iwazaki, W. Sugimoto, Y. Murakami; Electrochem. Commun., 2, 671 (2000).

15) G. M. Bancroft, I. Adams, L. L. Coatsworth, C. D. Bennewitz, J. D. Brown, W. D. Westwood; Anal. Chem., 47, 586 (1975).

16) Y. Abe, M. Kawamura, K. Sakai; Jpn. J. Appl. Phys., 38, 2092 (1999).

17) Y. Philip, L. Yijiang, T. Roger, L. Jing; J. Nanosci. anotechnol., 5, 1509 (2005).

18) C. Hagleitner, A. Hierlemann, D. Lange, A. Kummer, N. Kerness, O. Brand, H. Baltes; Nature, 414, 293 (2001). 